Article

\title{
Impact of Forest Fires on Air Quality in Wolgan Valley, New South Wales, Australia-A Mapping and Monitoring Study Using Google Earth Engine
}

\author{
Sachchidanand Singh ${ }^{1,2}$, Harikesh Singh ${ }^{1,2}$, Vishal Sharma ${ }^{1,2}$, Vaibhav Shrivastava ${ }^{1,2}$ (D), Pankaj Kumar ${ }^{3, *(D)}$

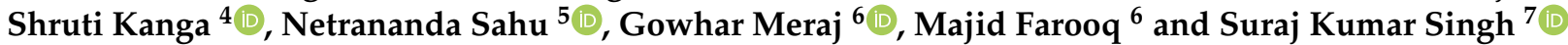 \\ 1 RBased Services Private Limited, Delhi 110086, India; sachin.iirs@gmail.com (S.S.); \\ harikeshsngh77@gmail.com (H.S.); vishal.iirs@gmail.com (V.S.); iirs.vaibhav@gmail.com (V.S.) \\ 2 Indian Institute of Remote Sensing, Dehradun 248001, India \\ 3 Institute for Global Environmental Strategies, Hayama, Miura-gun 240-0115, Kanagawa, Japan \\ 4 Centre for Climate Change \& Water Research, Suresh Gyan Vihar University, Jaipur 302017, India; \\ shruti.kanga@mygyanvihar.com \\ 5 Department of Geography, Delhi School of Economics, University of Delhi, Delhi 110007, India; \\ nsahu@geography.du.ac.in \\ 6 Department of Ecology, Environment and Remote Sensing, Government of Jammu and Kashmir, \\ Srinagar 190018, India; gowharmeraj@gmail.com (G.M.); majid_rsgis@yahoo.com (M.F.) \\ 7 Centre for Sustainable Development, Suresh Gyan Vihar University, Jaipur 302017, India; \\ suraj.kumar@mygyanvihar.com \\ * Correspondence: kumar@iges.or.jp
}

Citation: Singh, S.; Singh, H.; Sharma, V.; Shrivastava, V.; Kumar, P.; Kanga, S.; Sahu, N.; Meraj, G.; Farooq, M.; Singh, S.K. Impact of Forest Fires on Air Quality in Wolgan Valley, New South Wales, Australia-A Mapping and Monitoring Study Using Google Earth Engine. Forests 2022, 13, 4. https://doi.org/10.3390/f13010004

Academic Editors:

Any Mary Petritan, Mirela Beloiu and Timothy A. Martin

Received: 28 September 2021 Accepted: 19 December 2021 Published: 21 December 2021

Publisher's Note: MDPI stays neutral with regard to jurisdictional claims in published maps and institutional affiliations.

Copyright: (C) 2021 by the authors. Licensee MDPI, Basel, Switzerland. This article is an open access article distributed under the terms and conditions of the Creative Commons Attribution (CC BY) license (https:// creativecommons.org/licenses/by/ $4.0 /)$.

\begin{abstract}
Forests are an important natural resource and are instrumental in sustaining environmental sustainability. Burning biomass in forests results in greenhouse gas emissions, many of which are longlived. Precise and consistent broad-scale monitoring of fire intensity is a valuable tool for analyzing climate and ecological changes related to fire. Remote sensing and geographic information systems provide an opportunity to improve current practice's accuracy and performance. Spectral indices techniques such as normalized burn ratio (NBR) have been used to identify burned areas utilizing satellite data, which aid in distinguishing burnt areas using their standard spectral responses. For this research, we created a split-panel web-based Google Earth Engine app for the geo-visualization of the region severely affected by forest fire using Sentinel 2 weekly composites. Then, we classified the burn severity in areas affected by forest fires in Wolgan Valley, New South Wales, Australia, and the surrounding area through Difference Normalized Burn Ratio (dNBR). The result revealed that the region's burnt area increased to $6731 \mathrm{sq} . \mathrm{km}$ in December. We also assessed the impact of long-term rainfall and land surface temperature (LST) trends over the study region to justify such incidents. We further estimated the effect of such incidents on air quality by analyzing the changes in the column number density of carbon monoxide and nitrogen oxides. The result showed a significant increase of about $272 \%$ for Carbon monoxide and $45 \%$ for nitrogen oxides. We conclude that, despite fieldwork constraints, the usage of different NBR and web-based application platforms may be highly useful for forest management to consider the propagation of fire regimes.
\end{abstract}

Keywords: forest fire (FF); Google Earth Engine (GEE); burnt vegetation; difference normalized burn ratio (dNBR); normalized burn ratio (NBR)

\section{Introduction}

Forests are an essential natural resource that plays a crucial role in sustaining environmental sustainability. Forest health is a true predictor of the predominant ecological condition in the region. The frequent occurrence of forest fires (FFs) is one of the main reasons why most of our valuable flora have been depleted and distressed [1]. Further, the devastation from these deadly fires directly or indirectly impacts human beings [2]. Forest fires are also viewed as a potential human, ecological, economic, and environmental threat. 
Fire causes partial or complete forest canopy loss, altering radiation balance by increasing the surface albedo, water drainage, and increased soil erosion [3].

Using remote sensing to monitor, analyze, and restore burned regions has become an essential part of postfire mitigation efforts on a global and regional scale. It provides reliable and speedy data and enables rapid diagnosis across burned areas. This approach further demands innovative technologies in the prompt, cost-effective collection, encoding, and proper visualization of spatial information. Space technology benefits from the ability of a computer to store and process enormous amounts of data. In this regard, the Google Earth Engine - a remote sensing datasets processing cloud-based web platform [4-7]—plays a vital role. It offers an efficient assessment of the fire status and the corresponding environmental impact of wildfire through geo-visualization. Change identification (e.g., amid postfire and pre-fire images) models commonly utilize remote sensing in fire intensity mapping [8-10].

Satellite imagery identifies forest fires using special techniques, including the fire intensity measurement by the normalized burn ratio (NBR), intended to distinguish areas burnt. Numerous indices, including the difference Normalized Burn Ratio (dNBR), and the soil-adjusted vegetation index burned zone index, have been derived and compared in the past [11-13]. The most widely used index, dNBR, provides a fair description of various vegetation populations (e.g., $60-70 \%$ precision as opposed to field validation) of the spatial disparity in intensity within a single fire $[10,14]$. Even the Landsat satellite data's short-wave infrared (SWIR) band is appropriate for detecting moisture both in vegetation and soils, and the near-infrared reflection (NIR) band is sensitive to green pigment, i.e., chlorophyll levels in leafy vegetation [15]. Therefore, satellite imagery analysis proves to be a powerful method for measuring and evaluating the intensity of fires since they have a sufficient temporal and spatial resolution [16].

Forest fires have environmental consequences, as they release carbon that contributes to global warming and can eventually alter biodiversity [17]. Fire activity has a significant influence on air pollution, atmospheric composition, and the climate. The toxic and chemical reactive gases, such as methane, carbon dioxide $\left(\mathrm{CO}_{2}\right)$, carbon monoxide $(\mathrm{CO})$, hydrocarbons, nitrogen oxides $\left(\mathrm{NO}_{\mathrm{x}}\right)$, methyl chloride, and particulate matter are released. The emissions from forest fires are a significant source of carbon dioxide $\left(\mathrm{CO}_{2}\right)$, affecting interannual variability and biogeochemical processes with atmospheric impact. Carbon monoxide (CO), emitted by incomplete combustion, affects the national and global air quality. Nitrogen oxides $\left(\mathrm{NO}_{\mathrm{x}}\right)$, radical $\mathrm{OH}$, volatile organic compounds, and black carbon can create troposphere ozone depletion while particulate matter affects human health and negatively impacts climate [18-20]. Various tests to assess the air quality of forest fires have since been conducted in the past $[18,21,22]$. The variability in weather can have a considerable impact on the fire regimes. Past experiments have shown that short-term (seasonal to annual) precipitation shifts that affect the humidity content of the fuel are related to the volatility of wildfires [23-25]. Further, due to climate change, the world's mean temperature is increasing, which may increase the chances of forest fires $[4,24,26]$.

There have been many forest fires in the world recently, but the Australian forest fire has been the most powerful. By 9 March 2020, about 18.6 million hectares [27] had been burnt, at least 34 people killed [28-30], and more than 5900 buildings damaged [31]. About 1 billion animals were killed, and other endangered species could have been made extinct $[32,33]$. The objectives of this study were to estimate the forest fire footprints by utilizing Landsat- 8 satellite imageries, analyze the fire intensity classification efficiency using standard spectral indices, estimate the impact of long-term temperature and precipitation on forest fire incidents, evaluate the impact of forest fires on air quality, and development of an interactive visualization web-application for quick geo-visualization of the burn severity. This application has been implemented to raise awareness of Australia's forest fire issues using an advanced Google Earth Engine (GEE) cloud-based platform. 


\section{Materials and Methods}

\subsection{Study Area}

Australia is the sixth-largest nation in the world total-area-wise and Oceania's largest country. Twenty-six million people are mostly urbanized on the eastern seaboard. In Australia, semiarid and arid areas cover 50\%-75\% of the land [34]. The study region lies in the vicinity of Wolgan Valley near Lidsdale, Eastern Australia (Figure 1), areas hit by fires in 2019-2020. Wolgan Valley is a small valley on the Wolgan River in the New South Wales (NSW) region of Lithgow, Australia.

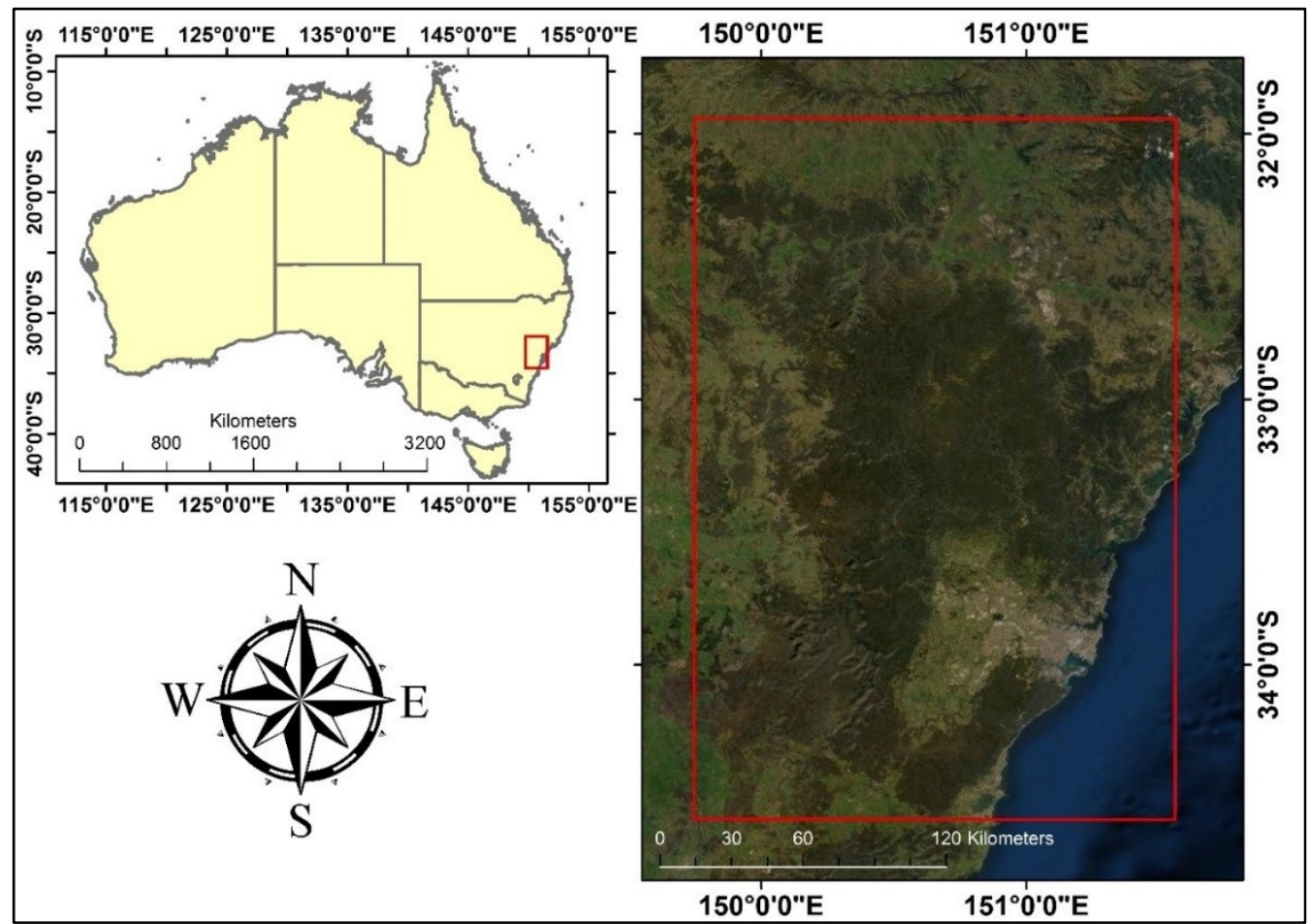

Figure 1. Location of the study areas. Wolgan Valley, near Lidsdale, Eastern Australia, is represented in the red box.

The valley lies about $32 \mathrm{~km}$ north of Lithgow and $150 \mathrm{~km}$ northwest of Sydney. Accessible from Castlereagh Highway via the Wolgan Valley Discovery Path (Wolgan Route), the route crosses the valley leading to Newnes historical village with its extensive industrial ruins. It runs wide east until it reaches the Capertee River and then the Colo River. The Wollemi Wilderness is the largest protected area in NSW and the largest in eastern Australia. The Wollemi protected area is 361,000 hectares east. Wolgan Valley comprises Wollemi National Park, Stone Gardens National Park, and the UNESCO World Heritage Region of Blue Mountains. Recently, in 2019, the region suffered from the hazardous incident of forest fire, which distressed flora and fauna of the region and deteriorated the air quality.

\subsection{Materials and Methods}

This study used the images from the Operational Land Imager (OLI) sensor of Landsat- 8 Satellite to map the burn severity. The images were acquired using an image export algorithm in Google Earth Engine. The temporal filter was applied for March, and October to December 2019. The minimum cloud cover imageries were chosen for the research area to help classify burned areas during the 2019 fire. Using the principles and elements of image interpretation (pattern, situation, association, size, shape, tone, NBR, and $\mathrm{dNBR}$ ), we identified the burnt patches and area, and the geospatial layer of the burnt area was generated. The overall methodology of this research is shown in Figure 2. For 
air quality monitoring, we used the Sentinel-5P dataset. CHIRPS (Climate Hazards Group Infrared Precipitation with Station) was used for rainfall time series estimation. The MODIS (Moderate Resolution Imaging Spectroradiometer) Terra Land Surface Temperature (LST) and Daily Emissivity dataset (MOD11A1.006) were used for validation. The details of the datasets are displayed in Table 1.

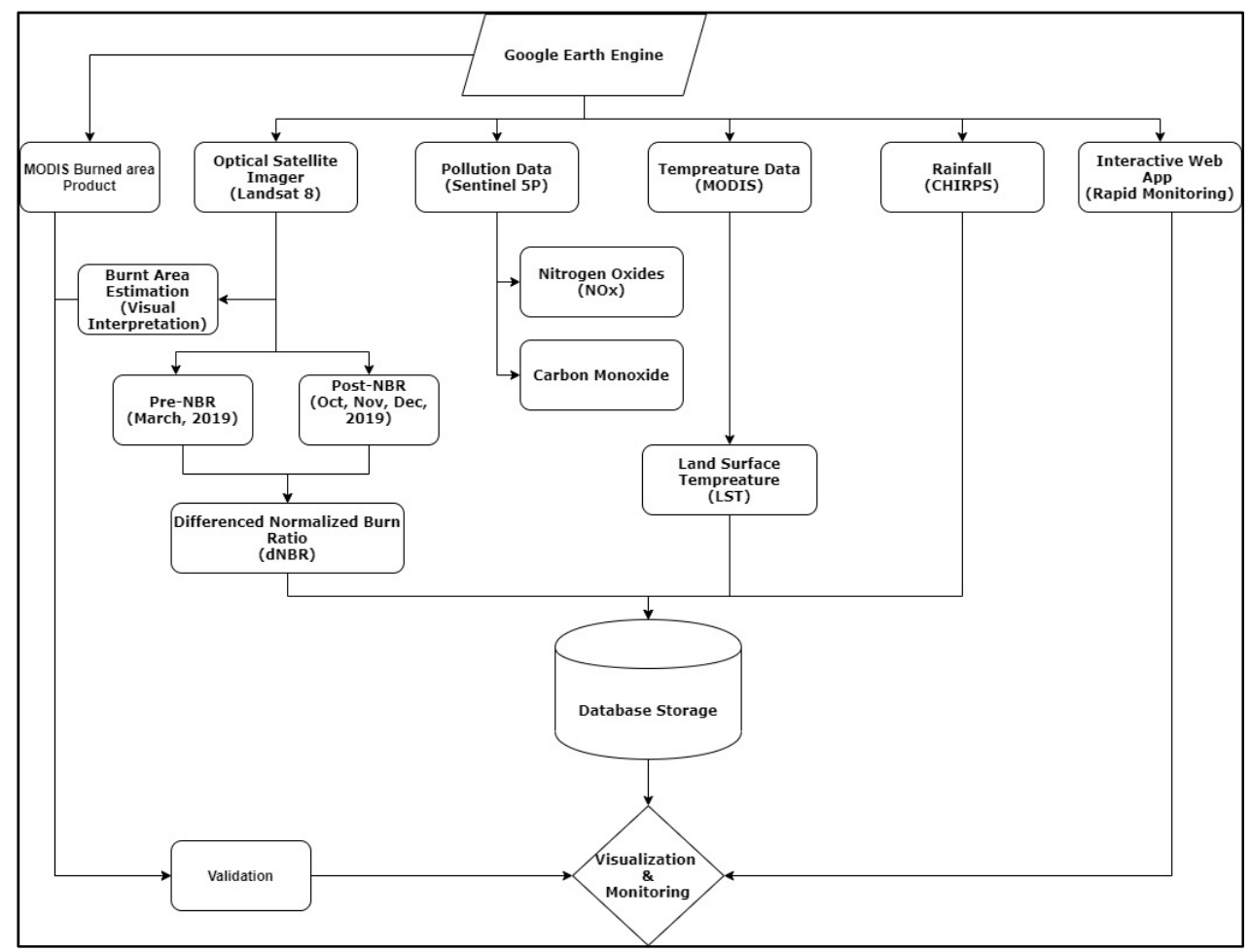

Figure 2. Overall methodology for this research.

Table 1. Various datasets employed in this research for burnt area estimation and pollution monitoring.

\begin{tabular}{|c|c|c|c|c|c|}
\hline S. No. & Purpose & Data & Duration & Resolution/Scale & Source \\
\hline 1 & Burned Area Mapping & $\begin{array}{l}\text { LANDSAT-8 Operational } \\
\text { Land Imager }\end{array}$ & $\begin{array}{l}\text { March, October, November, } \\
\text { December } 2019\end{array}$ & $30 \mathrm{~m}$ & \multirow{6}{*}{$\begin{array}{c}\text { Google Earth Engine } \\
\text { https: } \\
\text { // code.earthengine. } \\
\text { google.com/ } \\
\text { (Accessed on } \\
20 \text { August 2021). }\end{array}$} \\
\hline 2 & Web App Visualization & Sentinel 2 & $\begin{array}{c}\text { March, October, November, } \\
\text { December } 2019\end{array}$ & $10 \mathrm{~m}$ & \\
\hline 3 & Rainfall & CHIRPS daily & $1981-2019$ & $5000 \mathrm{~m}$ & \\
\hline 4 & $\begin{array}{l}\text { Land Surface } \\
\text { Temperature }\end{array}$ & MODIS Terra LST daily & 2001-2019 & $1000 \mathrm{~m}$ & \\
\hline 5 & $\begin{array}{l}\text { Pollution Mapping } \\
\text { and Monitoring }\end{array}$ & Sentinel 5P & $\begin{array}{c}\text { March, October, November, } \\
\text { December } 2019\end{array}$ & $1000 \mathrm{~m}$ & \\
\hline 6 & Validation & $\begin{array}{l}\text { MODIS Burned Area } \\
\text { Monthly }\end{array}$ & $\begin{array}{l}\text { October, November, } \\
\text { December } 2019\end{array}$ & $500 \mathrm{~m}$ & \\
\hline
\end{tabular}

\subsubsection{Spectral Indices}

The fire spectral index determines the edge of burning areas by normalization of burn ratio. The NBR is a normalized Burn Ratio index (see Equation (1)), based on the OLI sensor bands 5 and 7 reflectance data classifying burnt areas. Band 5 has a $30 \mathrm{~m}$ spatial resolution corresponding to Near-Infrared (NIR), equal to 0.85 - and $0.88-\mu \mathrm{m}$ spectral range; band 8 corresponds to SWIR, which has a $30 \mathrm{~m}$ spatial resolution equal to a $2.11-2.29 \mu \mathrm{m}$ spectral range. In determining multitemporal identification of change, we considered the bispectral SWIR-NIR bands $[16,35]$.

$$
\mathrm{NBR}=((\mathrm{NIR}-\mathrm{SWIR})) /((\mathrm{NIR}+\mathrm{SWIR}))
$$


where NIR represents Landsat-8 OLI sensor Band 5 and SWIR denotes Landsat-8 OLI sensor Band 7.

We also measured the dNBR using the bitemporal difference of the NBR images (see Equation (2)) [36]. Teobaldo and Baptista (2016) found that the dNBR strengthens the differences between the NBR scenes and emphasizes fire [37].

$$
\mathrm{dNBR}=\text { NBRpre }- \text { NBRpost }
$$

where NBRpre—pre-fire data, NBRpost—postfire data, and dNBR—difference NBR.

\subsubsection{Rainfall and Temperature Retrieval}

GEE makes fast analysis possible by using Google's machine infrastructure. For this study, CHIRPS, a quasi-global rainfall dataset, was coded to obtain Wolgan Valley's precipitation information from 1981 to 2019. We used GEE to determine the precipitation values around the study region with a $0.05^{\circ} \times 0.05^{\circ}$ daily temporal and spatial resolution. For the estimation of land surface temperature (LST), the MOD11A1.006 Terra LST dataset was processed in GEE to obtain the day surface temperature from 2001 to 2019. This method uses JavaScript coding on the GEE platform. The resulting chart was saved in 'csv' format.

\subsubsection{Pollution Monitoring}

The Nitrogen oxides and carbon monoxide datasets of Sentinel 5P satellite were retrieved using a GEE algorithm for pollution monitoring. Both Carbon monoxide (CO) and the Nitrogen oxides $\left(\mathrm{NO}_{2}\right.$ and $\left.\mathrm{NO}\right)$ are important trace gases in the atmosphere to understand tropospheric chemistry. The primary sources of $\mathrm{CO}$ and $\mathrm{NO}_{\mathrm{x}}$ include the combustion of fossil fuels, biomass burning in the atmosphere, and natural processes (wildfires, lightning, and microbiological mechanisms in soils). TROPOMI on the satellite Sentinel 5P measures CO global abundance using clear-sky and cloud-sky Earth's radiation parameters in the $2.3 \mu \mathrm{m}$-SWIR components of the solar spectrum. The TROPOMI $\mathrm{NO}_{2}$ processing method for OMI is based on the algorithm innovations for the DOMINO-2 software, and the EU QA4ECV NO 2 reprocessed dataset has been modified for TROPOMI. The datasets for March, October, November, and December 2019, were used to evaluate the change in air quality due to the forest fire.

\subsubsection{Web-App Development}

We have created a split-panel interactive geo-visualization app using GEE's create app feature. The weekly composites using Sentinel 2 Multispectral Instrument (MSI) Level-1C images were also created. Sentinel-2 is a wide-ranging, multispectral, high-resolution imaging initiative promoting Copernicus Land Monitoring studies involving vegetation mapping, soil and waters cover, and the study of inland and coastal waterways. Filter metadata function was used to filter out the images with a cloud pixel percentage of less than $30 \%$. For the proper visualization of the Fire event, False Color Composite was created using Bands 12 (Short-wave Infrared-2, $2202.4 \mathrm{~nm}$ ), 8 (Near-Infrared, $835.1 \mathrm{~nm}$ ), and 3 (Green, $560 \mathrm{~nm}$ ) over the median images. The min and max band values for visualization were set to 0 and 5000, respectively. For the pre-fire event, March's second week composites were taken; for the postfire event, the weeks of October, November, and December 2019 were taken. The desired weekly composites could be selected from the dropdown list provided in the corners of each panel for the users.

Various inbuilt functions of GEE such as ui.Map(), ui.Label(), ui.Select(), ui.Panel(), ui.SplitPanel(), and ui.Map.Linker() were used judiciously to this interactive app. The output window was split into two parts to visualize the changes in the fire events easily. This app also has a search toolbar at the top to directly examine the affected places. The created app could be accessed from https:/ / bit.ly / fires-aus (Accessed on 20 August 2021). This created app was used to visually analyze the zones deeply affected by forest fires over all of Australia. 


\section{Results and Discussion}

This section may be divided by subheadings. It should provide a concise and precise description of the experimental results, their interpretation, as well as the experimental conclusions that can be drawn.

\subsection{Web App Visualization}

Numerous places in Australia are severely affected by the forest fire. We developed the split-panel web-based application to analyze the change in the forest fire event visually. Some of the places severely affected were Wolgan Valley, NSW; Crawney, NSW; Nowendoc, NSW; and Nullo Mountains, NSW, as shown in Figures 3-6. The weekly composites of the images of Sentinel 2 were effective in visualizing forest fire growth.

Among all, Wolgan valley was taken as a study area from the most severely affected region, as shown by the web app.

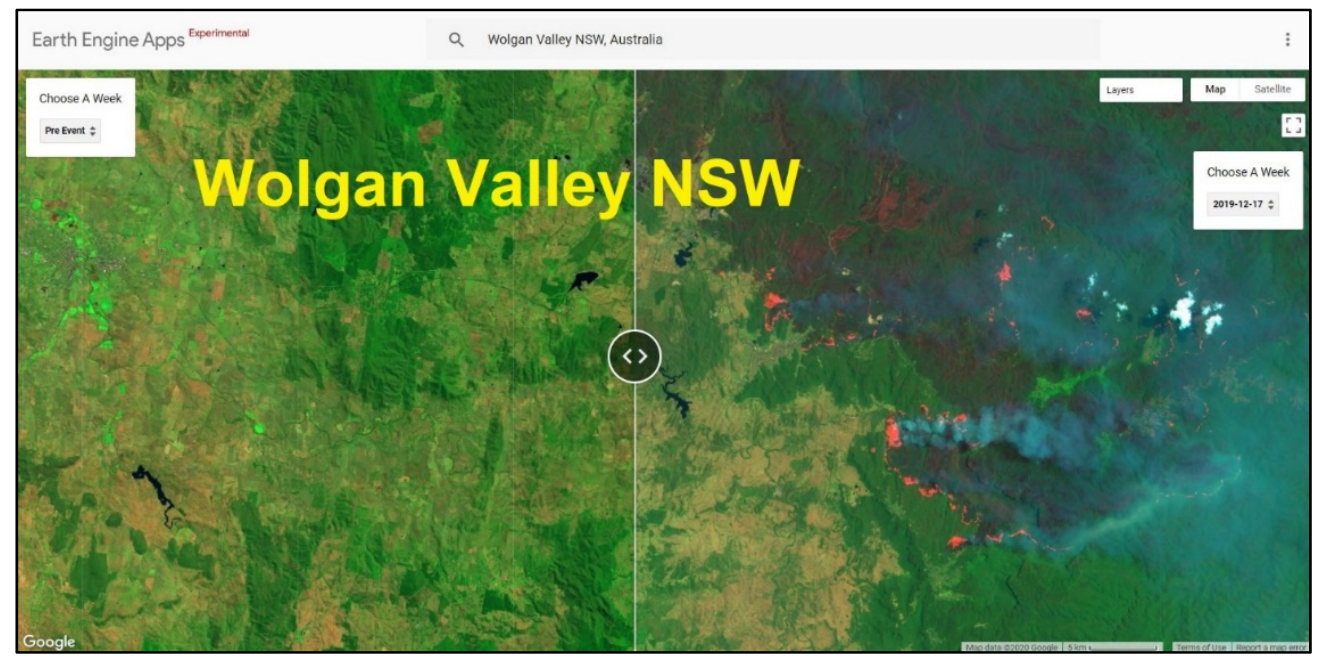

Figure 3. An overview of the Forest Fire web applications in Wolgan Valley, NSW, Australia.

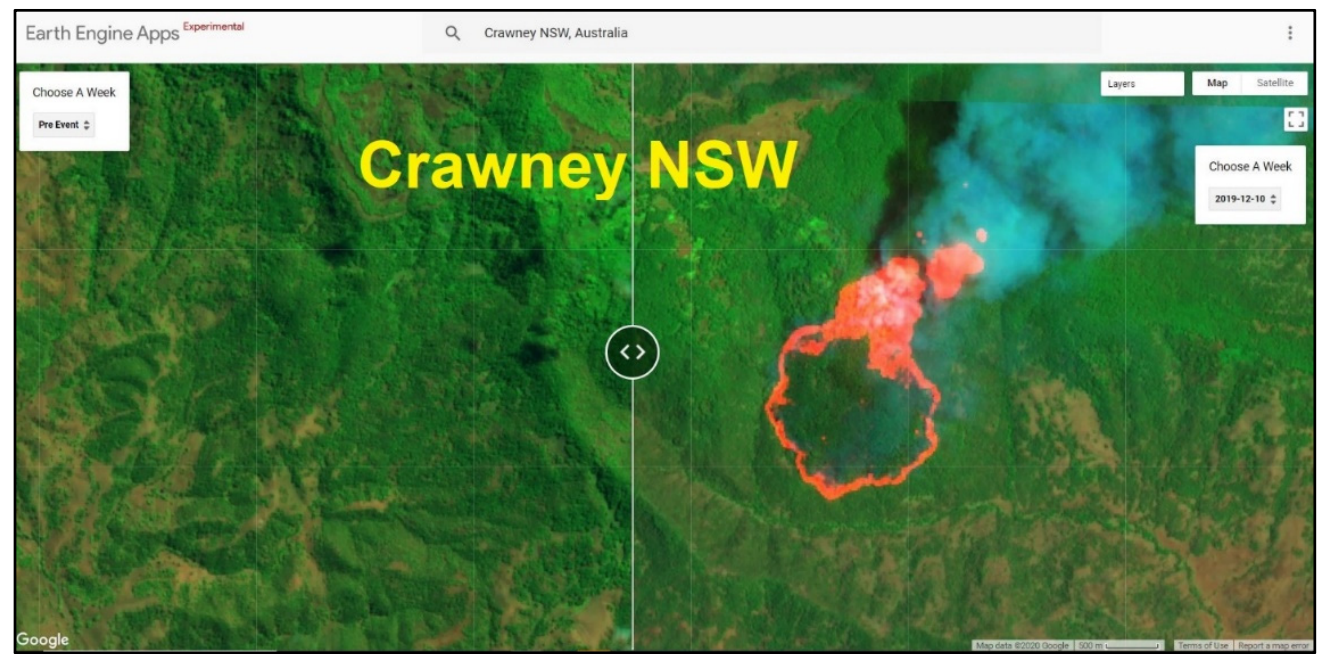

Figure 4. An example from the web app for a forest fire in Crawney, NSW, Australia. 


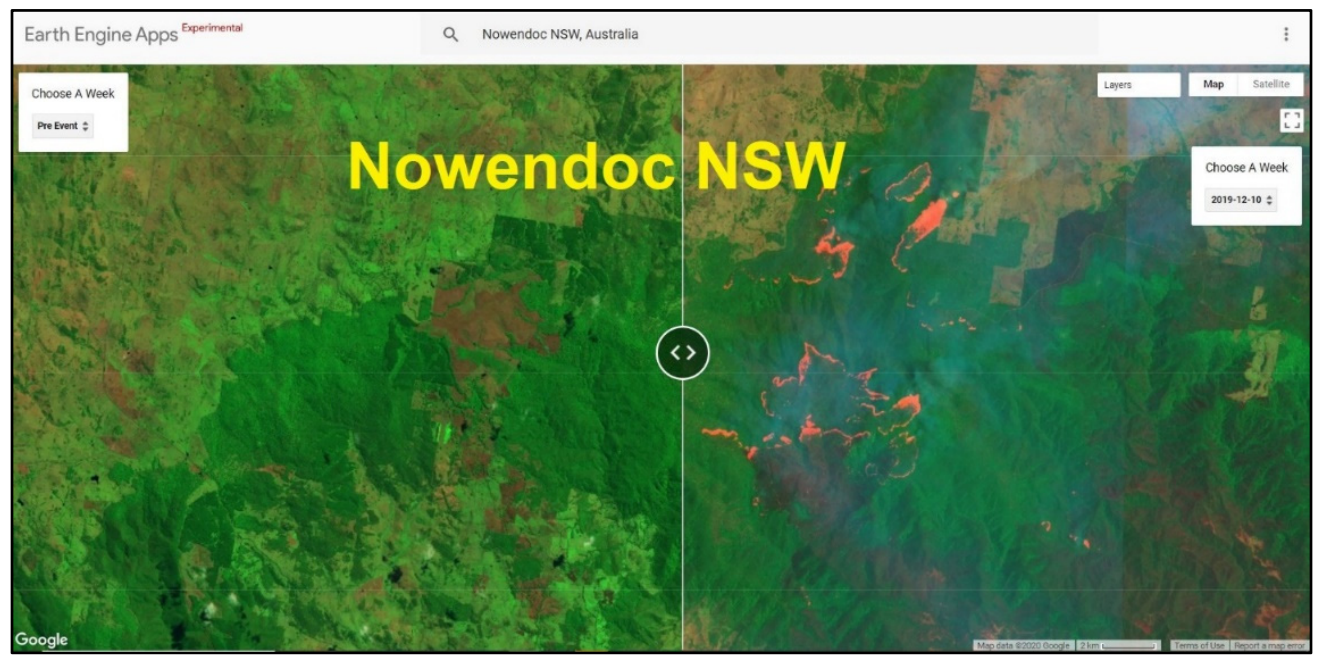

Figure 5. An example of the web app for visualizing forest fires in Nowendoc, NSW, Australia.

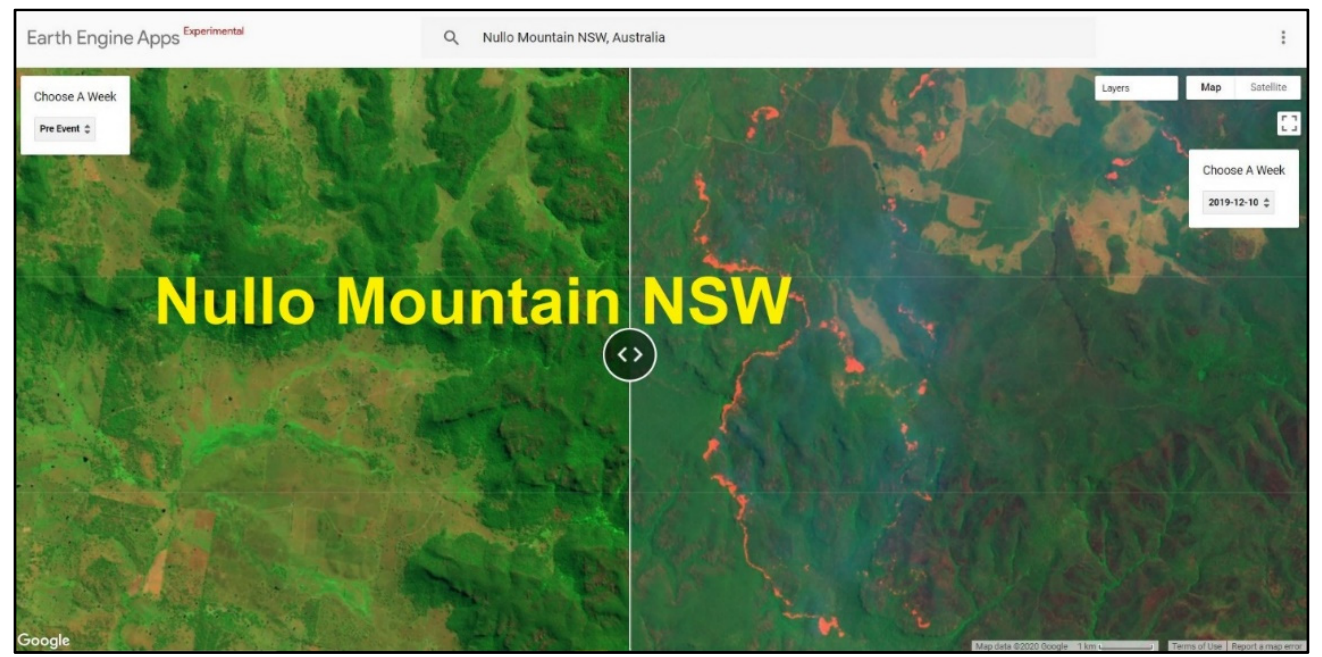

Figure 6. An example of the Forest Fire web app in Nullo Mountains, NSW, Australia.

\subsection{Rainfall and Temperature Variation}

Due to the warming climate, precipitation patterns and moisture levels change, leading to more dryness. The cooler air enhances the evaporation, leaving the soil drier by the atmosphere. Prolonged dry conditions are one of the driving factors behind forest fires. Dryness and high-temperature conditions cause the fire to occur frequently and exacerbate the length and severity of fires.

The annual rainfall time series analysis from 1981 to 2019 for Wolgan Valley was analyzed using the satellite-derived CHIRPS datasets in GEE (Figure 7). The region showed a decreasing trend (although insignificant) with a slope of -2.5 . However, for 2019, the region received an annual rainfall of $596 \mathrm{~mm}$, which is approximately $30 \%$ lower than the mean annual rainfall of $825 \mathrm{~mm}$ of the study area, which could be a major reason for the occurrence and enlargement of the forest fire. The Mann-Kendall Trend Test was also performed in order to obtain the trend behavior of the series; the test was performed based on yearly and yearly moving average. The test result is shown below in Table 2 .

As shown in Table 2, the time series shows no trend when yearly data are considered, but it starts showing the decreasing trend as we move for a more realistic approach of moving average in the test. All parameters obtained by performing the Mann-Kendall trend test are shown in Table 2. 


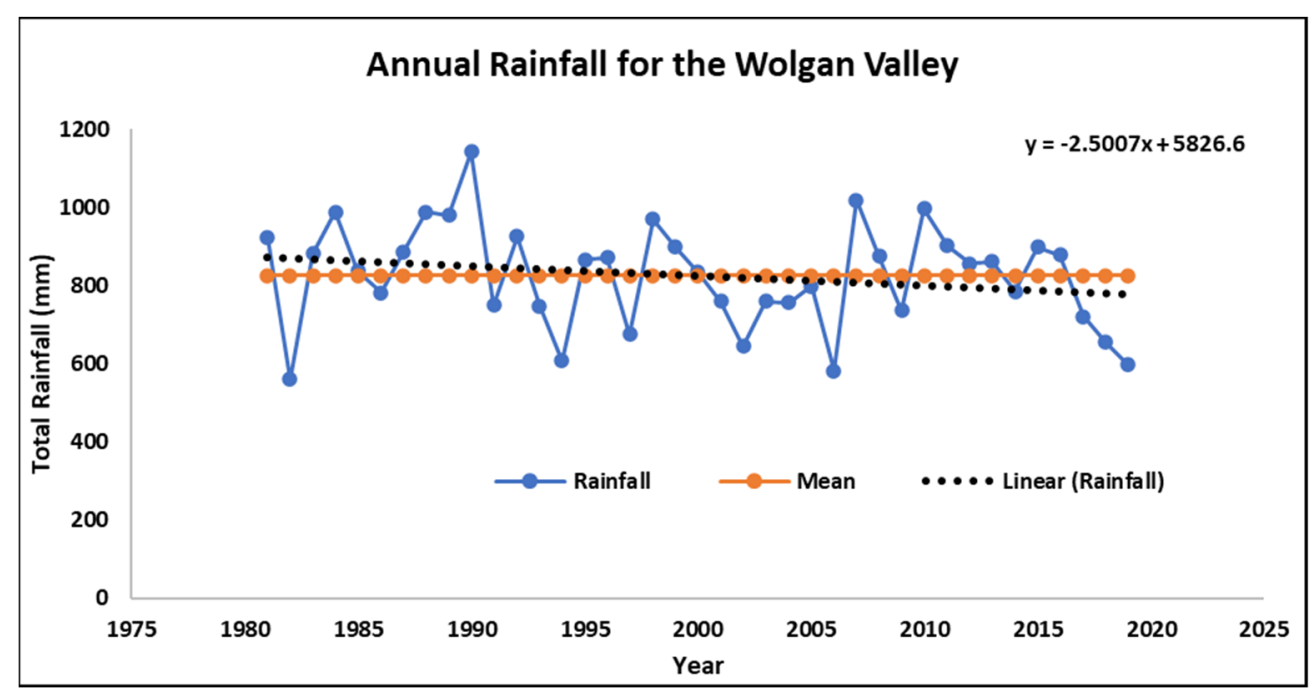

Figure 7. Annual rainfall time series from 1981-2019 for Wolgan Valley estimated from CHIRPS datasets in GEE.

The mean annual land surface temperature (LST) time series analysis during 2001 to 2019 for Wolgan Valley was performed using the satellite derived MOD11A1.006 Terra datasets in GEE (Figure 8), which found that the region showed an increasing trend with a slope of 0.0236 . Moreover, for the year of 2019, the region experienced the mean annual LST of $23.7^{\circ} \mathrm{C}$, which is approximately $8 \%$ higher than the mean annual LST of $21.9{ }^{\circ} \mathrm{C}$. The increase in temperature has a drying effect on the flora that could be one of the reasons for the forest fire events in the region.

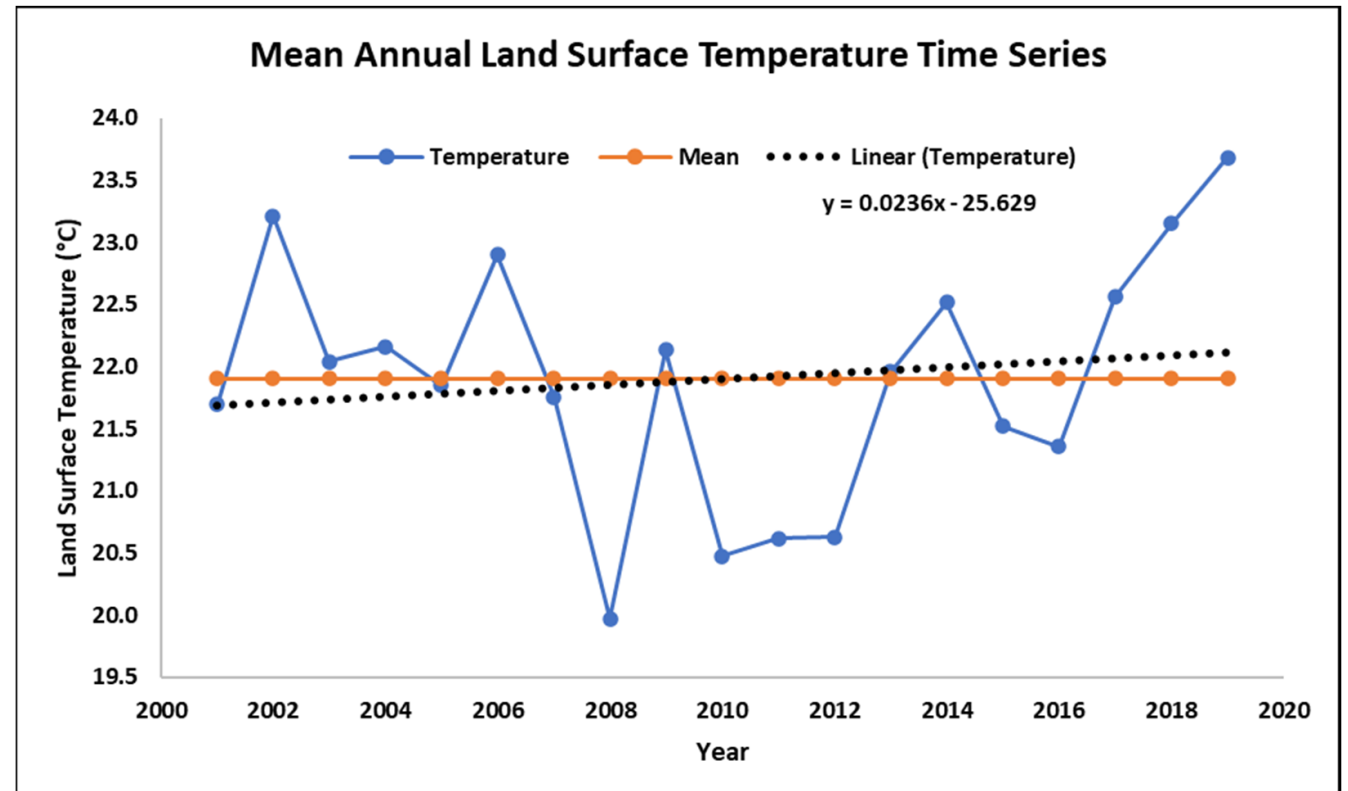

Figure 8. Annual mean land surface temperature (LST) from 2001-2019 for Wolgan Valley estimated from MODIS LST product datasets in GEE. 
Table 2. Trend analysis of CHIRPS rainfall data using Mann-Kendall moving average method.

\begin{tabular}{llllllllll}
\hline Time Period & Trend & $\mathbf{h}$ & $\boldsymbol{p}$ & $\mathbf{z}$ & Tau & $\mathbf{s}$ & var_s & Slope & Intercept \\
\hline Yearly & no trend & FALSE & 0.110313 & -1.59679 & -0.17949 & -133 & 6833.667 & -0.55886 & 48.80874 \\
\hline 2-yearly moving average & no trend & FALSE & 0.056014 & -1.91093 & -0.21764 & -153 & 6327 & -0.48733 & 48.69761 \\
\hline 3-yearly moving average & decreasing & TRUE & 0.008567 & -2.62886 & -0.3033 & -202 & 5846 & -0.56612 & 53.42137 \\
\hline 4-yearly moving average & decreasing & TRUE & 0.001132 & -3.25539 & -0.38095 & -240 & 5390 & -0.66736 & 58.51139 \\
\hline 5-yearly moving average & decreasing & TRUE & 0.000222 & -3.69237 & -0.43866 & -261 & 4958.333 & -0.72488 & 61.15642 \\
\hline
\end{tabular}

\subsection{Burnt Area Estimation}

The altitude for the bounding box ranges from 47 to $1599 \mathrm{~m}$ and is situated in the east of New South Wales. By analyzing the periodic increase in the geospatial boundary of burnt regions, we found it was $21 \mathrm{sq}$. $\mathrm{km}$ in October 2019, which increased to $912 \mathrm{sq}$. $\mathrm{km}$ in November 2019 primarily in the eastern region; later in December 2019, it further increased to $6731 \mathrm{sq} . \mathrm{km}$ with the growth in the east, north, and south directions (refer to Figure 9). So, it could be easily determined that the region suffered a severe overall increase of about 6710 sq. $\mathrm{km}$ within two months of the forest fire.

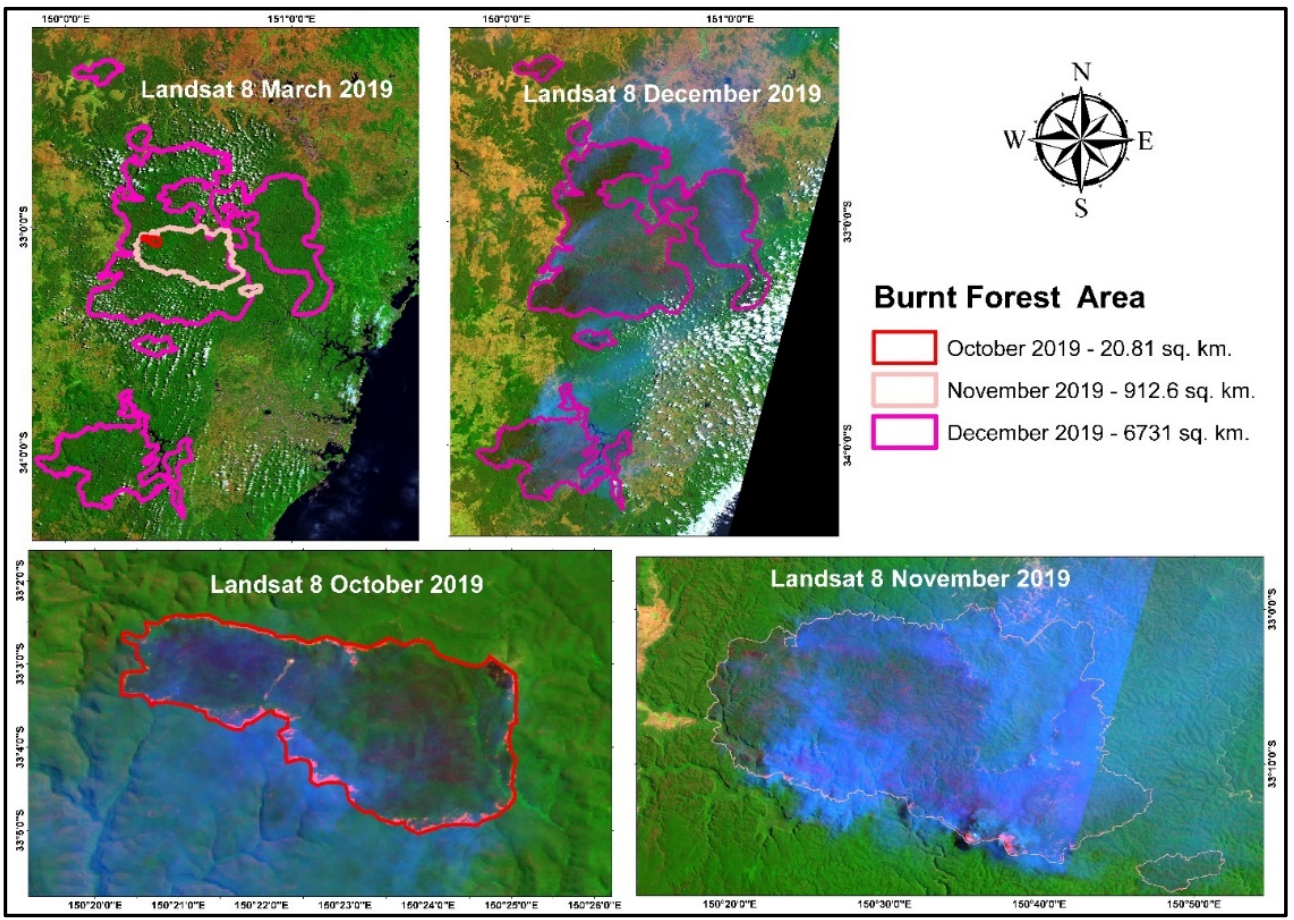

Figure 9. Map displaying the burned area footprints as estimated from visual interpretation.

The NBR multitemporal difference, i.e., due to their ease of application, the dNBR index has recently become the standard for fire intensity metrics using Landsat satellite data, as they typically provide a broad spectral range that can be accomplished between SWIR and NIR bands. The NBR pre-, NBR postestimation allows for the evaluation of change detection by multiple passes of thorough observation. From Equation (1), NBRpre and NBRpost values for the processed satellite imageries were observed. Key and Benson, (2006) who created the NBR, conceptualized the data-slicing index and suggested that the theoretical range spans from -1.0 to 1.0. An NBR near " 0 " means that clouds, grasses, exposed soil, or rocky outcrops can occur, and if pixels have a negative NBR, this implies extreme water stress on plants and the negative trace of a fire [38]. Thus, it is important to note that recent fire results usually vary from " 0 " to strongly negative. The dNBR (Equation (2)) combines multitemporal datasets of the NBR in one gradient, so the dNBR 
has a theoretical range from -2 to +2 . Positive dNBR values indicate a reduction in vegetation, while negative values are a rise in vegetation cover [10,14,39].

Table 3 shows NBR data from the Landsat- 8 image estimation for March, October, November, and December 2019. Concerning the NBR data for March 2019, it was found that pixel values ranged between -0.68 and +1.0 ; for October, the values ranged between -0.77 to 1; for November 2019, values ranged from -0.86 to +1.0 , while the NBR data of December 2019 was found between -0.87 and +0.88 .

Table 3. Theoretical and obtained bands, considering the pixels of Wolgan Valley, NSW NBR indices.

\begin{tabular}{ccc}
\hline Month & Theoretical Range & NBR \\
\hline Mar-19 & {$[-1$ to 1$]$} & {$[-0.68$ to +1$]$} \\
Oct-19 & {$[-1$ to 1$]$} & {$[-0.77$ to +1$]$} \\
Nov-19 & {$[-1$ to 1$]$} & {$[-0.86$ to +1$]$} \\
Dec-19 & {$[-1$ to 1$]$} & {$[-0.87$ to +0.88$]$} \\
\hline
\end{tabular}

The dNBR index for the severity groups was obtained using Equation (2). As such, Figure 10 shows the severity class for the fire burning in Wolgan Valley in the images used in this analysis. It is important to emphasize that the results of intensity display differences within the same burned area [36] and that determination and fire distribution perimeter, as well as the intensity within the fire, are useful for unit management managers seeking to grasp fire impacts on forests, such as the recovery of vegetation and postfire sequence for example $[16,39]$.

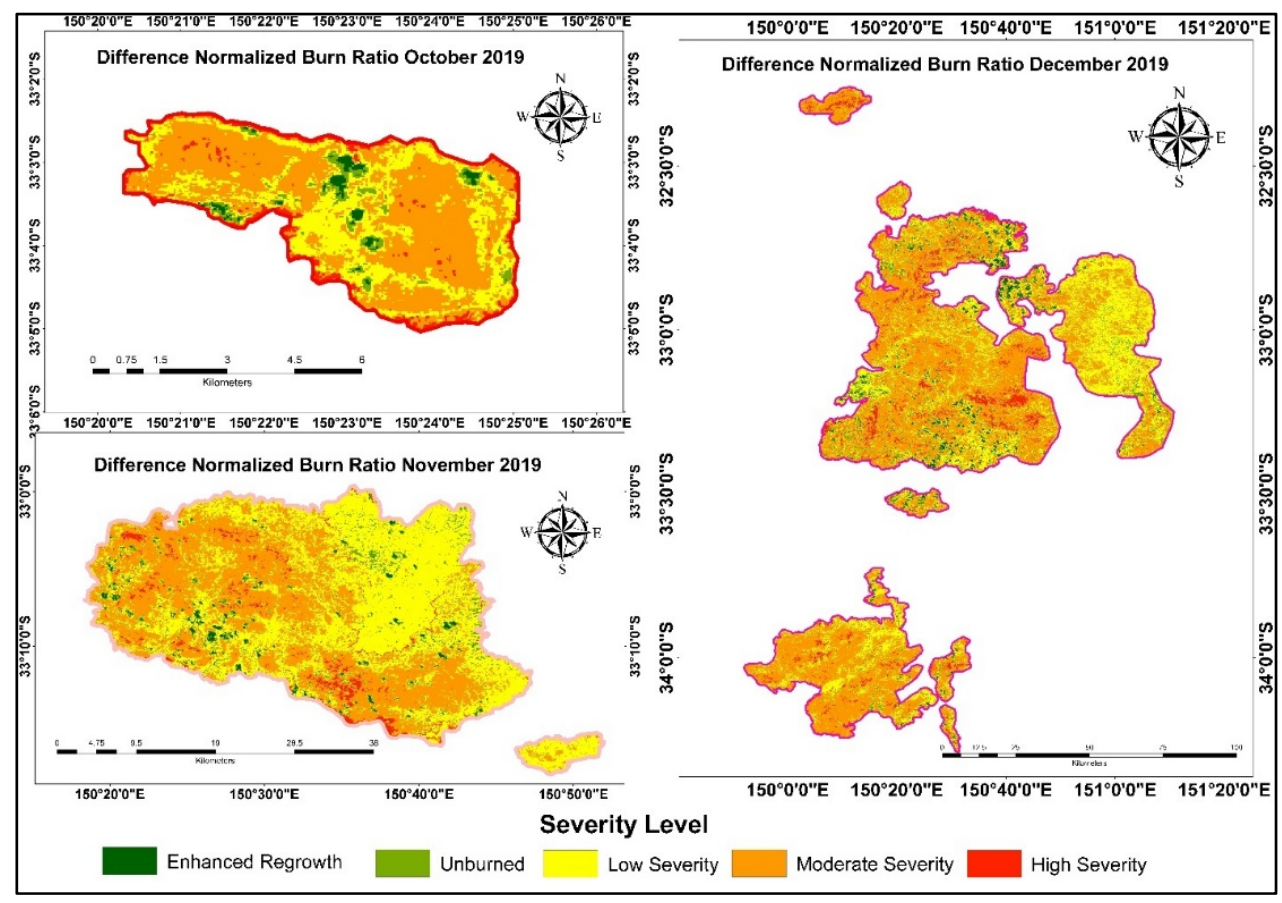

Figure 10. The dNBR indices for the identification of the severity level of the burnt area for Wolgan Valley, NSW.

The severity levels (Table 4) were used to classify the severity of indices. Moreover, we used a five-layer configuration, which has proven useful in several aspects. The dNBR value classes can differ between paired scenes. Values below -0.1 or greater than +0.66 may also exist, which may not be classified as burned. Alternatively, they are disguised as phenomena caused by lack of monitoring, clouds, or other causes not linked to actual ground cover variations. 
Table 4. Severity levels and dNBR interval.

\begin{tabular}{cc}
\hline Severity Level & dNBR Range \\
\hline Enhanced Regrowth & {$[>-0.1]$} \\
\hline Unburned & {$[-0.1$ to +0.1$]$} \\
\hline Low Severity & {$[+0.1$ to +0.27$]$} \\
\hline Moderate Severity & {$[+0.27$ to +0.66$]$} \\
\hline High Severity & {$[>+0.66]$} \\
\hline
\end{tabular}

The first level of severity reflects areas in which vegetation is present and can identify vegetation patches for postfire productivity. They occur almost entirely in vegetation where dNBR can be strongly negative, suggesting areas of improved after-fire efficiency (postfire NBR is much higher than pre-fire). Regular unburned pixels are located below zero. The last three stages include all other burned areas of which dNBR is explicitly constructive (postfire NBR is much less than pre-fire), including what is known as burned recently.

\subsection{Validation}

To validate the derived output of the burned area, the fire footprint for October and December 2019 were compared spatially with MCD64A1.006 MODIS Monthly Burned Area product obtained from GEE at 500 m-resolution as shown in Figure 11. On spatial interpretation, it was seen that the MODIS product overpredicted the burnt area derived from visual interpretation estimates for October and November. For October, MODIS product estimated the area to be $58 \mathrm{sq}$. $\mathrm{km}$ while, from Landsat- 8 OLI visual interpretation, the area obtained was $22 \mathrm{sq}$. $\mathrm{km}$. For December, MODIS product estimated the area to be 6205 sq. km while, from visual interpretation, the area obtained was $6731 \mathrm{sq}$. km. It could be stated that the visually interpreted region overlaps with the MODIS-derived burned area region. However, this variability could be due to the difference in their spatial resolution.

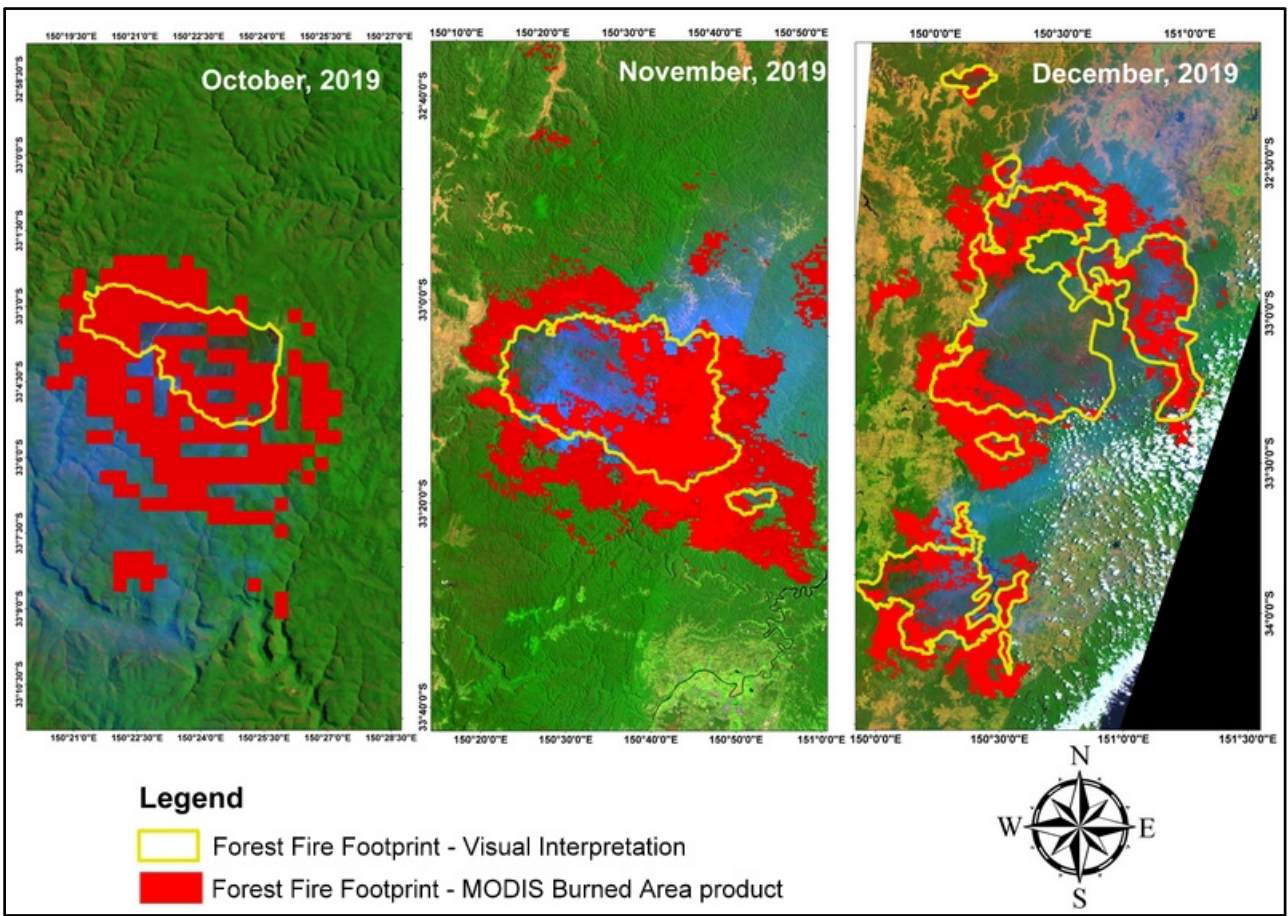

Figure 11. Forest fire footprints obtained by visual interpretation of Landsat-8 OLI and MODIS burned area products. 


\subsection{Impact on Air Pollution Due to the Forest Fire}

A significant fire event recently took place in the woods of Australia from October to December 2019. A total of 5,595,739 hectares have been burned, and 2475 houses and 25 lives have been lost in 10,520 bushfires in NSW. These incidents further resulted in heavy pollution, in the form of $\mathrm{CO}$ and $\mathrm{NO}$, in the vicinity of the event. For comparison, the air pollutants datasets were fetched for pre-fire and during-fire events.

It was found that the actual (satellite-based) mean spatial distribution of Carbon Monoxides Column Number Densities (COCND) (Figure 12) increased from $0.0177 \mathrm{~mol} / \mathrm{sq} . \mathrm{m}$. to $0.066 \mathrm{~mol} / \mathrm{sq}$. m. during March-December 2019 with $272 \%$ change. Further, the periodic observation exhibits that the minimum and maximum COCND were 0.014 and $0.021 \mathrm{~mol} / \mathrm{sq}$. m, respectively, in March 2019, which increased to 0.022 and $0.035 \mathrm{~mol} / \mathrm{sq} . \mathrm{m}$, respectively, in October 2019 with a 47\% increase. In November 2019, it increased to a minimum and maximum value of 0.021 and $0.11 \mathrm{~mol} / \mathrm{sq} . \mathrm{m}$, respectively, with $23 \%$ successive amplification mostly in the eastern direction. Later, in December 2019, the densities enlarged to a minimum and maximum value of 0.029 and $0.15 \mathrm{~mol} / \mathrm{sq} . \mathrm{m}$, respectively, with $103 \%$ incremental increase in almost every direction. The stats obtained for the COCND are shown in Figure 13.

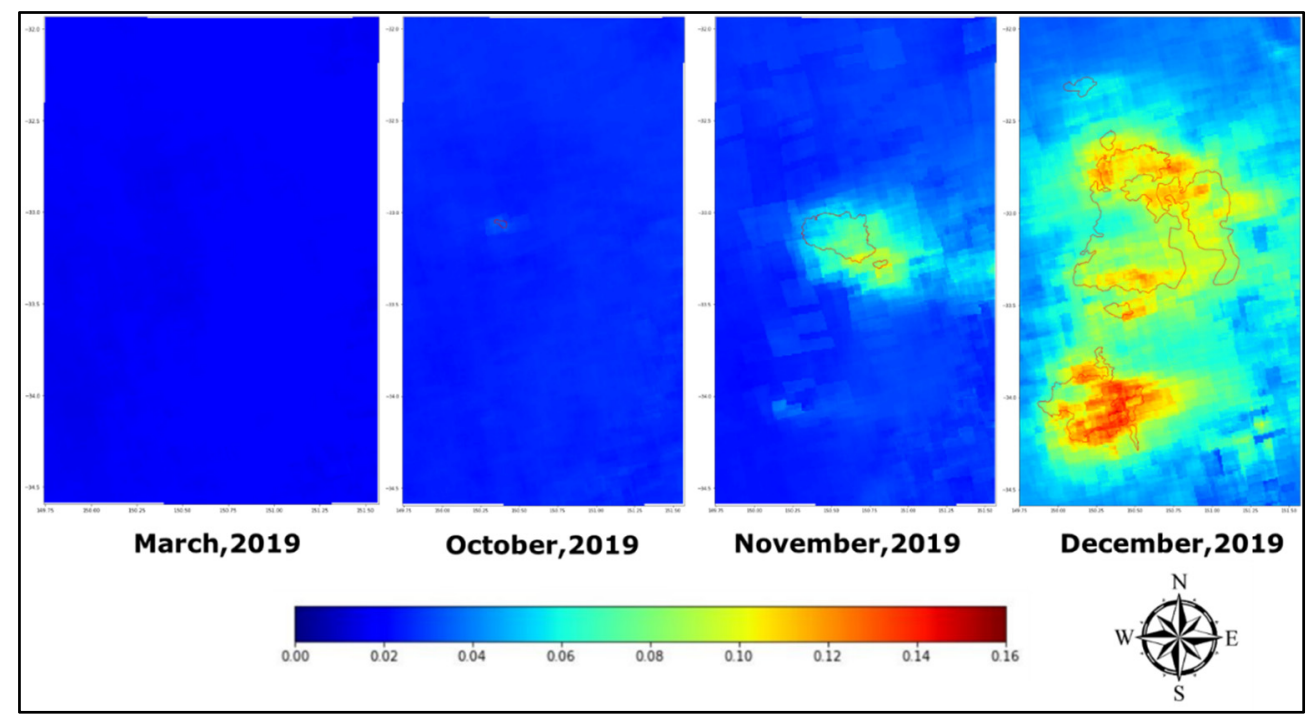

Figure 12. Maps showing the variation of COCND during the event of forest fire.

The obtained result could also be visualized from the histogram (Figure 14a) and violin graph (Figure 14b) of the COCND images for March, October, November, and December 2019. It is found that most of the pixel counts lie close to the value of $0.01 \mathrm{~mol} / \mathrm{sq} . \mathrm{m}$ for March; for the October month, it shifts towards $0.025 \mathrm{~mol} / \mathrm{sq}$. m. For November, the pixel spans with max counts close to $0.03 \mathrm{~mol} / \mathrm{sq}$. $\mathrm{m}$ and, finally, for December 2019, the pixels become very distributed with maximum counts close to the value of $0.05 \mathrm{~mol} / \mathrm{sq}$. $\mathrm{m}$.

Similarly, the overall trend of mean Nitrogen Oxides Column Number Densities (NOCND) (Figure 15), for the forest area was found to increase from $0.0000287 \mathrm{~mol} / \mathrm{sq} . \mathrm{m}$ to $0.0000416 \mathrm{~mol} / \mathrm{sq}$. m during March-December 2019 with 45\% change. It was observed that the minimum and maximum NOCND were 0.0000027 and $0.0002496 \mathrm{~mol} / \mathrm{sq} . \mathrm{m}$, respectively, in March 2019, which increased to 0.0000041 and $0.0002627 \mathrm{~mol} / \mathrm{sq}$. m, respectively, in October 2019 with a 10\% increase. In November 2019, it decreased to a minimum and maximum 0.0000033 and $0.0002478 \mathrm{~mol} / \mathrm{sq} . \mathrm{m}$, respectively, with a $6 \%$ decrease. However, again in December 2019, the densities increased to a minimum and maximum value of 0.0000033 and $0.0004636 \mathrm{~mol} / \mathrm{sq}$. m, respectively, with $40 \%$ incremental increase. The stats obtained for the NOCND is shown in Figure 16. 


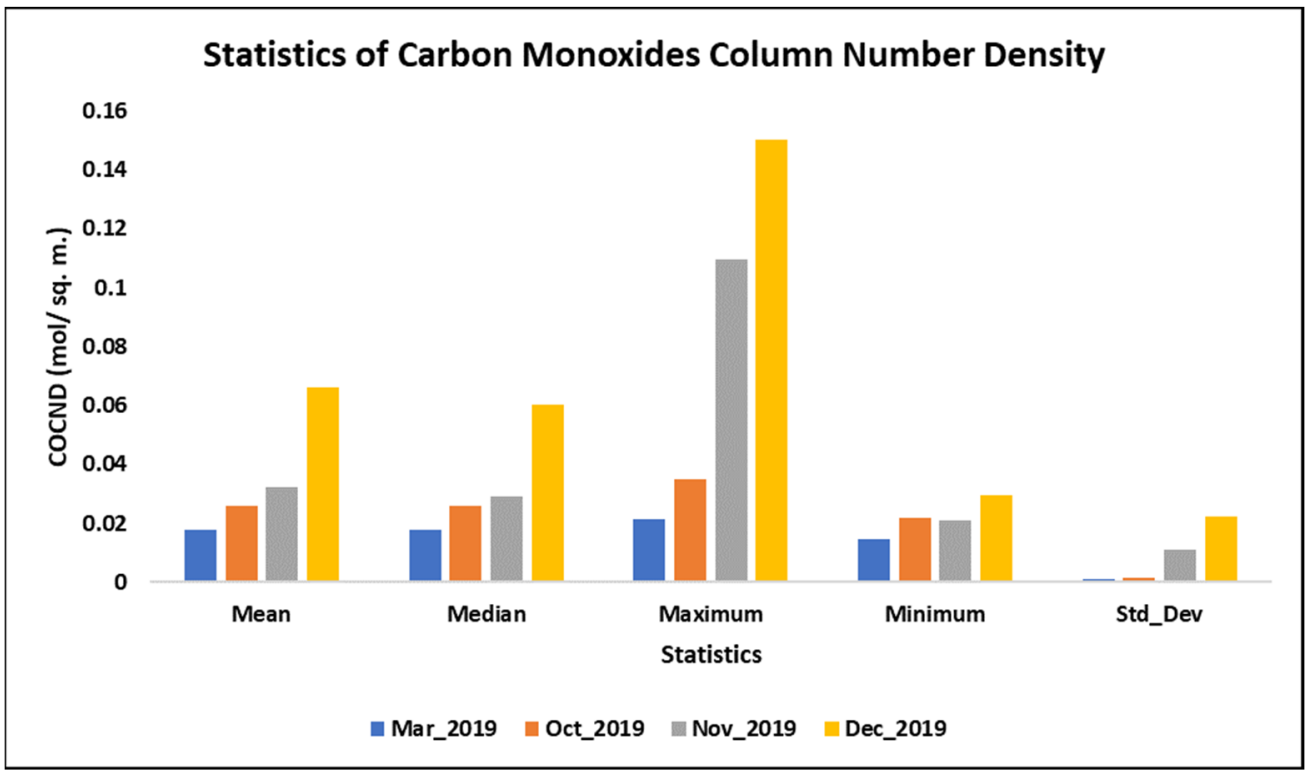

Figure 13. Statistics of COCND variation for the forest fire event.

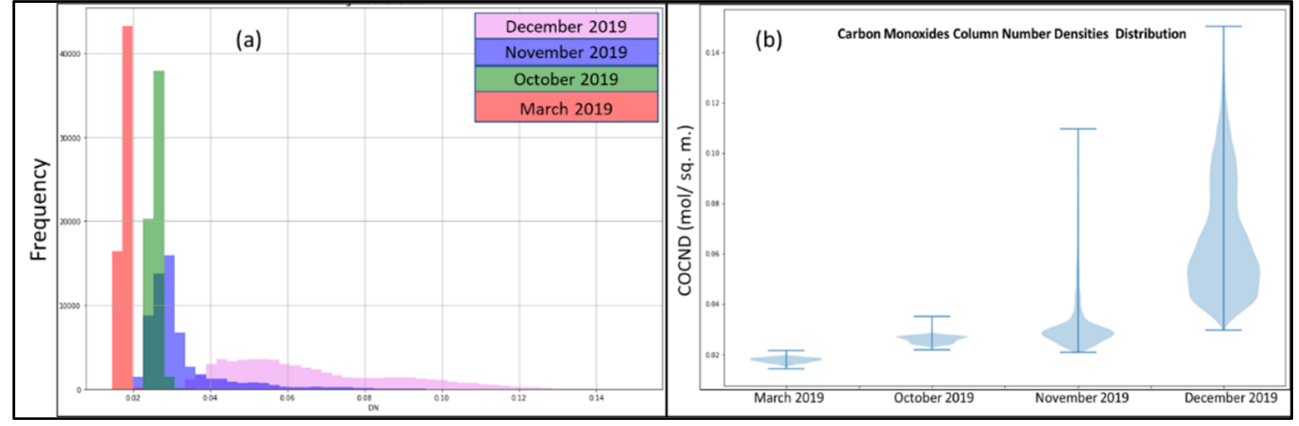

Figure 14. (a) Histogram and (b) Violin plot obtained for the COCND values for the forest fire incident.

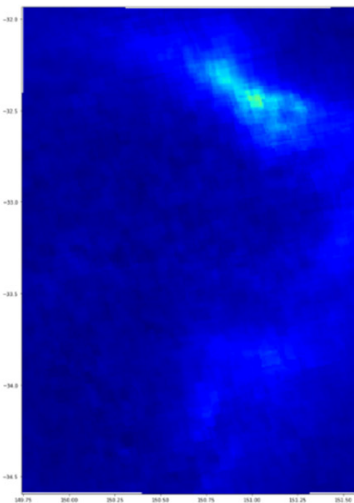

March, 2019

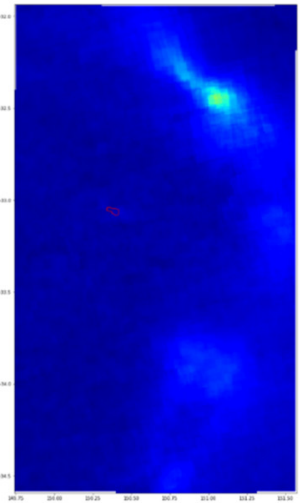

October, 2019

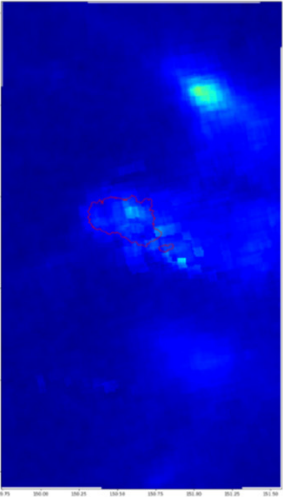

November, 2019

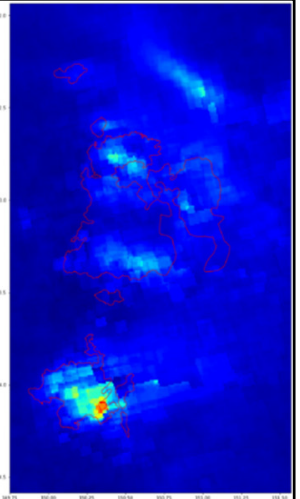

December, 2019

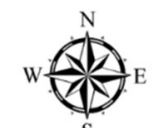

Figure 15. Maps showing the variation of NOCND during the event of forest fire. 


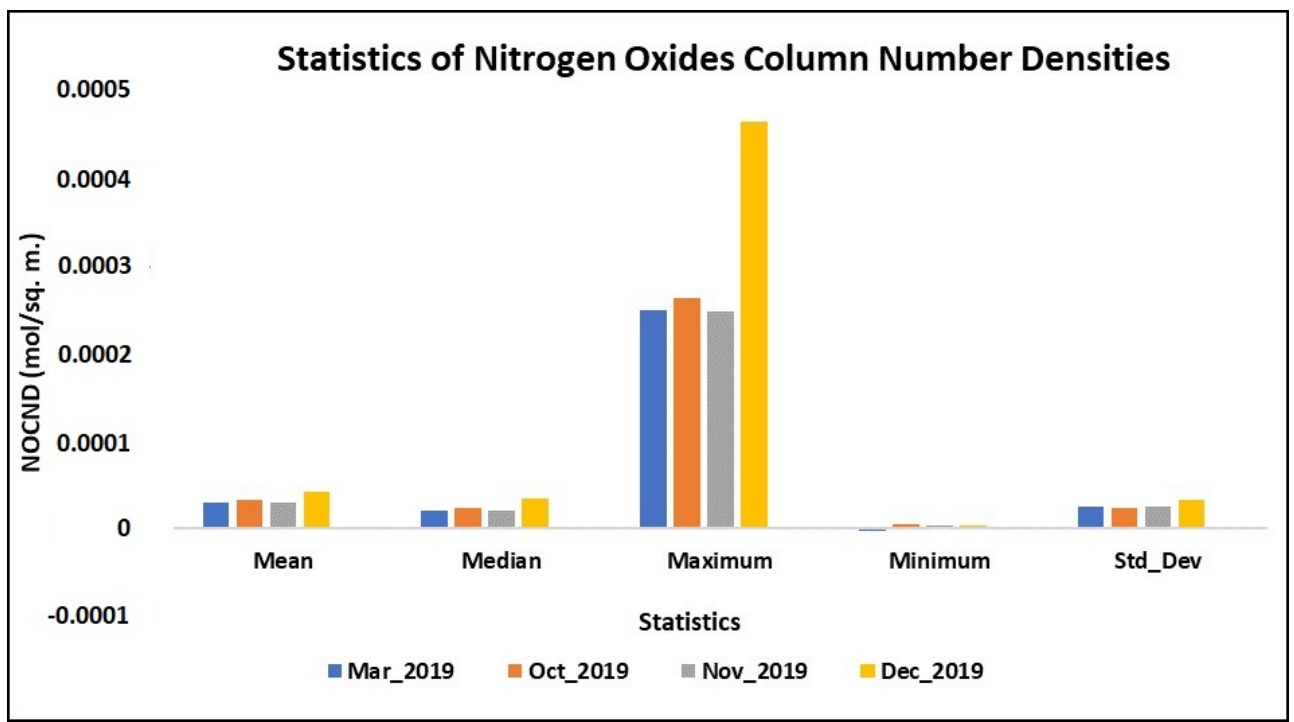

Figure 16. Statistics of NOCND variation for the forest fire event.

The obtained result could also be visualized from the histogram (Figure 17a) and violin graph (Figure 17b) of the NOCND images for March, October, November, and December 2019. It is found that most of the pixel counts lie close to the value of $0.0000116 \mathrm{~mol} / \mathrm{sq} . \mathrm{m}$ for March and, for October, it shifts towards $0.0000155 \mathrm{~mol} / \mathrm{sq}$. m. For November, the pixel value reduces to $0.000012 \mathrm{~mol} / \mathrm{sq}$. $\mathrm{m}$ and, finally, for December 2019, the pixels get distributed with maximum counts close to the value of $0.00002 \mathrm{~mol} / \mathrm{sq} . \mathrm{m}$.

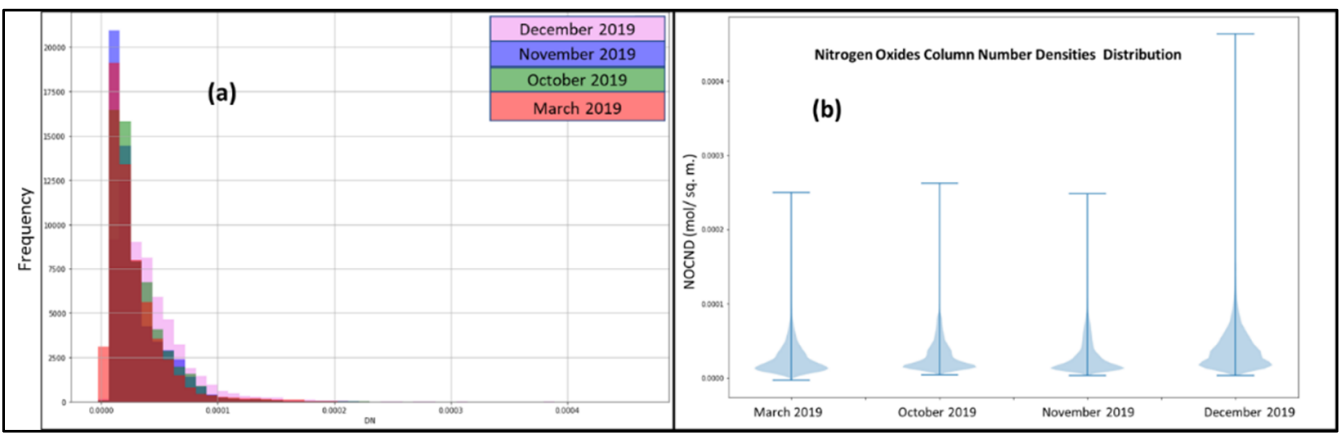

Figure 17. (a) Histogram and (b) Violin plot obtained for the NOCND values for the forest fire incident.

The increase in $\mathrm{CO}$ is attributed to incomplete biomass combustion. NO emissions are due to the high nitrogen content of biomass and new leaves. The analysis reveals that forest fire does not just affect the ecosystem in which it occurs, but also has effects on the surrounding regions.

\section{Conclusions}

Forest fires are one of the major sources of forest loss and air pollution. The NBR index was sensitive to pre- and postfire images of fire pixels in the SWIR-NIR region. Based on the methodology used in this work, the pre- and postfire difference index (dNBR) proved adequate to identify fire-affected pixels. The use of the dNBR index proved to be a valuable tool for the classification of burned areas in the region. It was found that the rate of loss of forest was very large (approx. $6730 \mathrm{sq} . \mathrm{km}$ ) at the time of the fire. It is necessary to consider that the temporal information obtained from Landsat satellite images can provide valuable data for efficient management of natural resources. Moreover, in the limitations of fieldwork, the use of GEE-based Web-application, the geo-visualization of the fire events became quick and easy. This application could be extremely beneficial for 
forest management to understand the spread of fire regimes, as it could contribute to the execution of effective environmental training actions and restoration.

Burning biomass also has a significant effect on air quality in nearby cities. During the fire period, major contaminants $\mathrm{CO}$ and NOx were found to increase compared with the pre-fire time-period. The long-term time series analysis of rainfall and temperature revealed their increasing trend in the region. It is hypothesized that, due to climate change, forest fire incidences may further increase in the coming years. The joint management from the forest department and local village communities is important in this context. Further, there is an urgent need for effective management practices and a better weather forecasting system to ensure proper monitoring of such incidents.

Author Contributions: Conceptualization, S.S., H.S., V.S. (Vaibhav Shrivastava), V.S. (Vishal Sharma) and G.M.; methodology S.S., H.S., V.S. (Vaibhav Shrivastava), V.S. (Vishal Sharma) and G.M.; software, S.S., H.S., V.S. (Vaibhav Shrivastava) and V.S. (Vishal Sharma); validation, S.S., H.S., V.S. (Vaibhav Shrivastava), V.S. (Vishal Sharma) and G.M.; formal analysis, S.S., H.S., V.S. (Vaibhav Shrivastava), V.S. (Vishal Sharma) and G.M.; investigation, S.S., H.S., V.S. (Vaibhav Shrivastava), V.S. (Vishal Sharma), P.K., S.K.S., N.S., M.F., S.K. and G.M.; resources, S.S., H.S., V.S. (Vaibhav Shrivastava), V.S. (Vishal Sharma), P.K., S.K.S., N.S., G.M., M.F. and S.K.; data curation, S.S., H.S., V.S. (Vaibhav Shrivastava), V.S. (Vishal Sharma), P.K., S.K.S., N.S., G.M., M.F. and S.K.; writing-original draft preparation, S.S., H.S., V.S. (Vaibhav Shrivastava) and V.S. (Vishal Sharma); writing-review and editing, S.S., H.S., V.S. (Vaibhav Shrivastava), V.S. (Vishal Sharma), P.K., S.K.S., N.S., G.M., M.F. and S.K.; visualization, S.S., H.S., V.S. (Vaibhav Shrivastava), V.S. (Vishal Sharma), P.K., S.K.S., N.S., G.M., M.F. and S.K.; supervision, S.S., H.S., S.S., V.S. (Vaibhav Shrivastava), V.S. (Vishal Sharma), S.K.S. and S.K.; project administration, P.K.; funding acquisition, P.K. All authors have read and agreed to the published version of the manuscript.

Funding: Publication fund for this work is supported by the Strategy Research Fund 2021 (WHNPlanetary-Health), an in-house grant from Institute for Global Environmental Strategies (IGES).

Institutional Review Board Statement: Not Applicable.

Informed Consent Statement: Not Applicable.

Data Availability Statement: Data are available on request from the corresponding author.

Acknowledgments: The authors S.S., H.S., V.S. (Vaibhav Shrivastava) and V.S. (Vishal Sharma) are thankful to R-Based Services Private Limited, Delhi, India, for providing the necessary setup for conducting this research. The author G.M. is thankful to the Department of Science and Technology, Government of India (DST-GoI) for providing the Fellowship under Scheme for Young Scientists and Technology (SYST-SEED) [Grant no. SP/YO/2019/1362(G) \& (C)].

Conflicts of Interest: The authors declare no conflict of interest.

\section{References}

1. Prasad, A.S.; Pandey, B.W.; Leimgruber, W.; Kunwar, R.M. Mountain hazard susceptibility and livelihood security in the upper catchment area of the river Beas, Kullu Valley, Himachal Pradesh, India. Geoenviron. Disasters 2016, 3, 1. [CrossRef]

2. Yao, J.; Raffuse, S.M.; Brauer, M.; Williamson, G.J.; Bowman, D.M.; Johnston, F.H.; Henderson, S.B. Predicting the minimum height of forest fire smoke within the atmosphere using machine learning and data from the CALIPSO satellite. Remote Sens. Environ. 2018, 206, 98-106. [CrossRef]

3. Beck, K.; Mariani, M.; Fletcher, M.-S.; Schneider, L.; Aquino-López, M.; Gadd, P.; Heijnis, H.; Saunders, K.; Zawadzki, A. The impacts of intensive mining on terrestrial and aquatic ecosystems: A case of sediment pollution and calcium decline in cool temperate Tasmania, Australia. Environ. Pollut. 2020, 265, 114695. [CrossRef]

4. Gibson, R.; Danaher, T.; Hehir, W.; Collins, L. A remote sensing approach to mapping fire severity in south-eastern Australia using sentinel 2 and random forest. Remote Sens. Environ. 2020, 240, 111702. [CrossRef]

5. Gorelick, N.; Hancher, M.; Dixon, M.; Ilyushchenko, S.; Thau, D.; Moore, R. Google Earth Engine: Planetary-scale geospatial analysis for everyone. Remote Sens. Environ. 2017, 202, 18-27. [CrossRef]

6. Mab, P.; Ly, S.; Chompuchan, C.; Kositsakulchai, E. Evaluation of Satellite Precipitation from Google Earth Engine in Tonle Sap Basin, Cambodia. In Proceedings of the THA 2019 International Conference on Water Management and Climate Change towards Asia's Water-Energy-Food Nexus and SDGs, Bangkok, Thailand, 23-25 January 2019. 
7. Singh, S.; Dhasmana, M.K.; Shrivastava, V.; Sharma, V.; Pokhriyal, N.; Thakur, P.K.; Aggarwal, S.P.; Nikam, B.; Garg, V.; Chouksey, A.; et al. Estimation of revised capacity in Gobind Sagar reservoir using Google Earth Engine and GIS. ISPRS-Int. Arch. Photogramm. Remote Sens. Spat. Inf. Sci. 2018, XLII-5, 589-595. [CrossRef]

8. Chafer, C.J.; Noonan, M.; Macnaught, E. The post-fire measurement of fire severity and intensity in the Christmas 2001 Sydney wildfires. Int. J. Wildland Fire 2004, 13, 227-240. [CrossRef]

9. Lentile, L.B.; Holden, Z.A.; Smith, A.; Falkowski, M.J.; Hudak, A.T.; Morgan, P.; Lewis, S.A.; Gessler, P.E.; Benson, N.C. Remote sensing techniques to assess active fire characteristics and post-fire effects. Int. J. Wildland Fire 2006, 15, 319-345. [CrossRef]

10. Miller, J.D.; Thode, A.E. Quantifying burn severity in a heterogeneous landscape with a relative version of the delta Normalized Burn Ratio (dNBR). Remote Sens. Environ. 2007, 109, 66-80. [CrossRef]

11. Kasischke, E.S.; Turetsky, M.R.; Ottmar, R.D.; French, N.H.F.; Hoy, E.E.; Kane, E.S. Evaluation of the composite burn index for assessing fire severity in Alaskan black spruce forests. Int. J. Wildland Fire 2008, 17, 515-526. [CrossRef]

12. Smith, A.M.; Eitel, J.U.; Hudak, A.T. Spectral analysis of charcoal on soils: Implications for wildland fire severity mapping methods. Int. J. Wildland Fire 2010, 19, 976-983. [CrossRef]

13. Marino, E.; Guillen-Climent, M.; Ranz Vega, P.; Tomé, J. Fire severity mapping in Garajonay National Park: Comparison between spectral indices. FLAMMA 2016, 7, 22-28.

14. Soverel, N.O.; Perrakis, D.D.; Coops, N.C. Estimating burn severity from Landsat dNBR and RdNBR indices across western Canada. Remote Sens. Environ. 2010, 114, 1896-1909. [CrossRef]

15. Meng, Q.; Meentemeyer, R.K. Modeling of multi-strata forest fire severity using Landsat TM Data. Int. J. Appl. Earth Obs. Geoinf. 2011, 13, 120-126. [CrossRef]

16. Escuin, S.; Navarro, R.; Fernández, P. Fire severity assessment by using NBR (Normalized Burn Ratio) and NDVI (Normalized Difference Vegetation Index) derived from LANDSAT TM/ETM images. Int. J. Remote Sens. 2007, 29, 1053-1073. [CrossRef]

17. Kollanus, V.; Tiittanen, P.; Niemi, J.; Lanki, T. Effects of long-range transported air pollution from vegetation fires on daily mortality and hospital admissions in the Helsinki metropolitan area, Finland. Environ. Res. 2016, 151, 351-358. [CrossRef]

18. McMahon, C.K. Forest fires and smoke-Impacts on air quality and human health in the USA. In Proceedings of the TAPPI International Environmental Conference, Nashville, TN, USA, 18-21 April 1999; TAPPI Press: Nashville, TN, USA, 1999; Volume 2 , pp. 443-453.

19. Yin, S.; Wang, X.; Guo, M.; Santoso, H.; Guan, H. The abnormal change of air quality and air pollutants induced by the forest fire in Sumatra and Borneo in 2015. Atmos. Res. 2020, 243, 105027. [CrossRef]

20. Yuchi, W.; Yao, J.; McLean, K.E.; Stull, R.; Pavlovic, R.; Davignon, D.; Moran, M.D.; Henderson, S.B. Blending forest fire smoke forecasts with observed data can improve their utility for public health applications. Atmos. Environ. 2016, 145, 308-317. [CrossRef]

21. Adetona, O.; Reinhardt, T.E.; Domitrovich, J.; Broyles, G.; Adetona, A.; Kleinman, M.T.; Ottmar, R.D.; Naeher, L.P. Review of the health effects of wildland fire smoke on wildland firefighters and the public. Inhal. Toxicol. 2016, 28, 95-139. [CrossRef]

22. Langmann, B.; Duncan, B.; Textor, C.; Trentmann, J.; van der Werf, G. Vegetation fire emissions and their impact on air pollution and climate. Atmos. Environ. 2009, 43, 107-116. [CrossRef]

23. Bernard, M.; Bernard, L. Correlation between Wildfire Statistical Data, Weather and Climate. 2007. Available online: https: / / ams.confex.com/ams/pdfpapers/126829.pdf (accessed on 20 August 2021).

24. Trauernicht, C. Vegetation-Rainfall interactions reveal how climate variability and climate change alter spatial patterns of wildland fire probability on Big Island, Hawaii. Sci. Total Environ. 2019, 650, 459-469. [CrossRef] [PubMed]

25. Whitworth-Hulse, J.I.; Magliano, P.N.; Zeballos, S.R.; Gurvich, D.E.; Spalazzi, F.; Kowaljow, E. Advantages of rainfall partitioning by the global invader Ligustrum lucidum over the dominant native Lithraea molleoides in a dry forest. Agric. For. Meteorol. 2020, 290, 108013. [CrossRef]

26. Bar, S.; Parida, B.R.; Pandey, A.C. Landsat-8 and Sentinel-2 based Forest fire burn area mapping using machine learning algorithms on GEE cloud platform over Uttarakhand, Western Himalaya. Remote Sens. Appl. Soc. Environ. 2020, 18, 100324. [CrossRef]

27. Burton, J. It Was a Line of Fire Coming at Us': South West Firefighters Return Home. 2020. Available online: https://www. busseltonmail.com.au/story/6620313/it-was-a-line-of-fire-coming-at-us-firefighters-return-home/ (accessed on 20 August 2021).

28. ABCNews. Victorian Bushfires Death Toll Rises as Authorities Confirm Contractor's Death Was Fire-Related. 2020. Available online: https:/ / www.abc.net.au/news/2020-01-15/fires-death-toll-rises-to-five-in-victoria/11869596 (accessed on 20 August 2021).

29. Green, M. Australia's Massive Fires Could Become Routine, Climate Scientists Warn. 2020. Available online: https: / / www.reuters.com/article/us-climate-change-australia-report/australias-massive-fires-could-become-routine-climatescientists-warn-idUSKBN1ZD06W (accessed on 20 August 2021).

30. SBSNews. The Numbers Behind Australia's Catastrophic Bushfire Season. 2020. Available online: https://www.sbs.com.au/ news/the-numbers-behind-australia-s-catastrophic-bushfire-season (accessed on 20 August 2021).

31. O'Mallon, F.; Tiernan, E. Australia's 2019-2020 Bushfire Season. 2020. Available online: https://www.canberratimes.com.au/ story /6574563/australias-2019-20-bushfire-season/ (accessed on 20 August 2021).

32. Readfearn, G. "Silent Death": Australia's Bushfires Push Countless Species to Extinction. 2020. Available online: https://www theguardian.com/environment/2020/jan/04/ecologists-warn-silent-death-australia-bushfires-endangered-species-extinction (accessed on 20 August 2021). 
33. The University of Sydney. More Than One Billion Animals Killed in Australian Bushfires. 2020. Available online: https://www. sydney.edu.au/news-opinion/news/2020/01/08/australian-bushfires-more-than-one-billion-animals-impacted.html (accessed on 20 August 2021).

34. Zaman, M.A.; Rahman, A.; Haddad, K. Regional flood frequency analysis in arid regions: A case study for Australia. J. Hydrol. 2012, 475, 74-83. [CrossRef]

35. Veraverbeke, S.; Lhermitte, S.; Verstraeten, W.; Goossens, R. The temporal dimension of differenced Normalized Burn Ratio (dNBR) fire/burn severity studies: The case of the large 2007 Peloponnese wildfires in Greece. Remote Sens. Environ. 2010, 114, 2548-2563. [CrossRef]

36. Roy, D.P.; Boschetti, L.; Trigg, S.N. Remote sensing of fire severity: Assessing the performance of the normalized burn ratio. IEEE Geosci. Remote Sens. Lett. 2006, 3, 112-116. [CrossRef]

37. Teobaldo, D.; Baptista, G.M.D.E. Measurement of severity of fires and loss of carbon forest sink in the conservation units at Distrito Federal. Rev. Bras. Geogr. Fis. 2016, 9, 250-264. [CrossRef]

38. Key, C.H.; Benson, N.C. Landscape Assessment: Ground Measure of Severity, the Composite Burn Index; and Remote Sensing of Severity, the Normalized Burn Ratio. 2006. Available online: http://pubs.er.usgs.gov/publication/2002085 (accessed on 20 August 2021).

39. Dos Santos, S.M.B.; Bento-Gonçalves, A.; Franca-Rocha, W.; Baptista, G. Assessment of burned forest area severity and postfire regrowth in chapada diamantina national park (Bahia, Brazil) using dnbr and rdnbr spectral indices. Geosciences 2020, 10, 106. [CrossRef] 